\title{
The Impact of Multiple Electoral Processes in the Evolution of the Conduct Iraqi Voters After 2003
}

\author{
Khamees Hezam Wali \\ University of Baghdad, Baghdad, Iraq \\ Riad Ghazi Al-Badran \\ The Independent Higher Commission for Elections in Iraq, Najaf, Iraq
}

\begin{abstract}
The topic area of the research deals with election in Iraq and new electoral system which is considered as new features of Iraqi political system based on participation and multiparty system; the researchers argued that the process of elections has not provided an opportunity for concrete progress on the path of democracy; it has not made any significant contribution to the process of political change, and it has provided the opportunity for researchers and analysts to rationalize mechanism of authority in Iraq after 2003. The researchers argued the Iraqi electoral behavior in the federal parliamentary elections since 2005 to 2014, and there is no need to keep track of the voting behavior by voters, but it needs to check the basis of the appellation of the electoral lists and make them be based on national principles, rather than sectarian and ethnic principles. The voting behavior of the Iraqi voters is often influenced by the social composition of the community, and the researchers argued that the continuation of the electoral process periodically will contribute significantly to the changing in their locally based voting behavior to nationally based voting behavior.
\end{abstract}

Keywords: elections, behavior, electoral behavior, parties, sharing

The parliamentary elections reflect the evolution of the political system, regardless of whether it is real or evolution formality. However, it particularly reflects an important appearance democracy and the foundations of popular participation in it. And it is the nature of dominant electoral behavior, and the aspects of this behavior are changing. Therefore, in general, elections play a major role in the political process and democracy. In parliamentary countries, in particular with recent experiment states in this process, such as Iraq, once the election occurs, replication is an important indicator of this behavior. In the same context, it provides an opportunity for the political parties to express their presence by introducing programs and developing the general national goals, in addition to being an important opportunity to increase awareness and political mobilization through political education, and public participation in the election process itself.

Despite the great importance of elections and the need to hold them properly and regularly, this is not one of the democratic process indicators, and not for the whole democratic process, which is involving more and more indicators connected to society and the various regulations. Election has its importance beyond the purely

Corresponding author: Khamees Hezam Wali, Ph.D., assistant professor of Political and Constitutional Systems, College of Political Science, University of Baghdad, Bagdad, Iraq; research fields: elections and electoral systems and political parties.

Riad Ghazi Al-Badran, Ph.D., the Independent Higher Commission for Elections in Iraq, Najaf, Iraq; research fields: elections and electoral systems and political parties. 
political sector, in the sense that it is in force and influential on society and reflects a lot of the new or the old values, and behaviors of the election of its members.

The elections after 2003 represent a new electoral experience. And it confirmed that Iraq suspends to the periodical parliamentary elections. Regardless of the conditions associated with it, it did not provide an opportunity for concrete progress on the road to democracy mature. It did not come to any significant political change. It provided the opportunity for researchers and analysts to deepen understanding of the nature of power and the mechanisms of power in Iraq after the change.

To read the Iraqi electoral behavior in the federal parliamentary elections of 2005-2014, we see the need to keep track of the voting trends for voters and the appellations of the electoral lists, which competed in those elections, by dividing Iraq territorially and demographically of Iraqi land into the fields in order to do these entities and electoral weight, by relying on official data and statistics for election results, because it can give a clear picture on all the voting trends of the Iraqi voters. Making process to rely on some other mechanisms, such as the questionnaire, to know the behavior of voters, may be inaccurate, because of the changing of voter's opinion before and after the elections.

The trends in voting behavior of the Iraqi voters are often influenced by the social composition of the community, as the voting behavior is a division indicator or social differentiation by linking behavior and choice of social belonging of election voters. It is influenced by the social environment and spatial space. So, electoral studies focused part of its work on the geography of the vote and the design of electoral maps, such as Siegfried. And seeing from Peter Taylor and Colin Flint, the spatial or geographic factor is of extreme importance to vote. People may vote for the candidate or the electoral lists by virtue of friendship, and there is a general tendency to get a candidate on many voices in his hometown and in the region to which he belongs and he grew up. Also, each geographic region is dominated by one issue of the issues that dominate the attention of the voters. The nature of circulating information affecting the decision to vote is largely influenced by the local network of social relations.

In addition to the nature of Iraqi society, its composition is heterogeneous and multiple, and varied determinants are influencing the attitudes and behavior of voters, incarnated in various legal and regulatory frameworks, and religious institutions. However, these frameworks and institutions differ among themselves in the degree of impact on voter's behavior. On the other hand, no one denies that the religious establishment, the forces, and Islamist parties, perhaps are the most capable of directing voters, in line with the views and positions, mainly by virtue of the role of religious reference, in building the political and constitutional process, and by virtue of its popularity, and ownership of a vast network of organizations and institutions, religious and cultural, as well as mosques and Al-Husainiat scattered in the whole country.

Sectarian and national polarization was clear in the Iraqi political scene, which was built on the basis of ethnic and sectarian quotas, and it is intensified in the parliamentary election season, which made lineups of behavioral voters to take the same direction. Identifying the nature of the Iraqi electoral behavior and electoral trends should be studied, according to social affiliations of Iraqi groups, with all their ratings, whether at ethnic level, or regionally, through the analysis of the election results, expressing orientations of the Iraqi groups.

This study was divided into four sections and conclusions as following:

(1) The first topic: the electoral map of political entities and coalitions;

(2) The second topic: political awareness and political participation; 
(3) The third topic: variation rate of participation in elections (2005-2010-2014);

(4) The fourth topic: political stability.

\section{The First Topic: The Electoral Map of Political Entities and Coalitions}

\section{Shiite Electoral Lists}

Shiites represent the numerical majority in Iraq. But they suffered a political ideological repression which led to its distance from political participation. Representing intellectually and politically in sectarian identity regulates its members. On this basis, and sometimes bounded together by family and tribal ties, at the same time gives them an Iraqi dimension, as it represents the majority in Iraq. But this view may be narrow, because this approach may not represent all the Shiites in Iraq. There are large numbers of Shiites who do not include them in the framework of political organization-religious (sectarian). And the majority of Shiites do not belong to political parties or political organizations. We can say that the growing Shiite political activities after 2003 may not always be associated with religion, as it is about the identity. When the majority of the Shiites voted to the United Iraqi Alliance in the Constituent Assembly elections in 2005, it represented the first occasion that was able to show the standing political and numerical superiority, which gave them the opportunity to decide the constitutional composition of the country. In the parliamentary elections of 2010, it has established voting behavior on the foundations of sectarian/ethnic and that was ended by 2014 parliamentary elections.

Through constituting the electoral map of Shiite, Sunni, and Kurdish political entities, as well as minorities of political entities who participate in the electoral process, we can mark the most prominent variables, which represent the split of Shiite bloc already broken in the coalition (State of Law Coalition and the Iraqi National Coalition) in parliamentary elections in 2010.

In the 2014 elections, blocs were fragmented to a number of coalitions and entities, which represent the most prominent parties and the dominant powers in the Shiite center and the government, and affect the extent of division and political competition among these forces and parties on the one hand; influenced by the nature-based electoral system, it also stimulates those forces and parties to contest the election lists of factional individually. Most notably, State of Law Coalition led by Nouri al-Maliki Coalition included the Dawa Party and the Badr Organization headed by Hadi al-Amiri; the mass of independent, headed by Hussein al-Shahristani; and the Coalition of the Liberal, which included entities Sadrist within the average St Lego System and a coalition of citizens, led by Ammar al-Hakim; Islamic Virtue Party entered the election with a list called the coalition of virtue and independent elites. And the Reform Movement was led by Ibrahim al-Jaafari. These political entities competed in the predominantly Shiite constituencies, namely, the governorate of Baghdad and Basra, Maysan, Dhi Qar, Wasit, Diwaniyah, Babil, Najaf, Karbala, and Muthanna, while those entities entered into a single list in a number of mixed governorate such as demographics (Salahuddin, Kirkuk, Mosul), except Diyala which ran in individual lists.

\section{Sunni Electoral Lists}

The Sunni join in parties and religious organizations just as the Shia. The prevailing pattern of political mobilization in Sunni areas is still tribal, with the breach of religious forces, Sufi and Salafi (fundamentalist Islamist).

Until recently, the Sunni culture lacks religious authority, such as the Shiite authority, the task of religious powers such as the Islamic Party, and the elders of the Sufis, the Association of Muslim Scholars, which was 
founded after the occupation and other ${ }^{1}$. Because of the position of occupation, the Sunni Arabs did not participate in 2005 National Assembly elections. But they rectify the mistake by forming strong alliance and electoral lists participated in all elections since 2005. Sunni political blocs exposed to split, just as the Shiite blocs. This can be seen by looking at the electoral map.

The most prominent blocs of it,

(1) Muttahidoon: headed by the former House Speaker Osama al-Nujaifi, which included a number of tribal nature, such as some political entities (Baghdad belt grouping headed by Talal Khudair Zubai, the national assembly of tribal headed by Omar Hegel, and the awakening of Iraq headed by Ahmed Bzag, gathered clans or Rabiein led by Hassan Khalaf), some with nature expressive of some regions or cities such as geographical (National Federation of the land of the people of Sharqat led by immolated Hussein), as well as some civilian trends entities ${ }^{2}$;

(2) Coalition Al-Arabiya: headed by Deputy Prime Minister Saleh al-Mutlaq, with Arab nationalist trends;

(3) Coalition Diyala Is Our Identity: headed by Saleem Aljobory, it focuses on the Diyala province, as well as some of territorial entities such as the expression (Coalition Loyalty to Al-Anbar, the entity Dignity);

(4) Those entities focused on competing mainly in Sunni areas such as Anbar, Nineveh, and Salahuddin; entered into a coalition and one was in Diyala province; as well as competed with each other such as the Arab coalition, united and reformed in the province of Baghdad ${ }^{3}$.

\section{Secular Electoral Lists}

The secular mainstream transit communities represent a number of electoral lists, especially in the 2014 parliamentary elections, the most important one of which-National Coalition led by Ayad Allawi, included a number of electoral entities and represented the Iraqi spectrum geographically and ethnically.

(1) Althalv Civic Democratic headed by Ali Kadhim. It included a number of electoral entities, most notably, the Iraqi Communist Party;

(2) Aitlav Iraq. It included a number of lists of prohibited terms of geography and ethnic composition.

These entities competed in most Iraqi provinces from the north to the south, and it was not limited to a circle or a certain constituency.

\section{Kurdish Electoral Lists}

Including political and pluralism party which was until recently shared between the main parties, the Patriotic Union of Kurdistan led by Jalal Talabani, and the Kurdistan Democratic Party, headed by Masoud Barzani, until the parliamentary elections in Kurdistan in 2005. Soon, the matter changed by forming Chande or Goran party, headed by Nawshirwan Mustafa, and the increased activity of the Kurdish Islamist parties, "Islamist group headed by Mohamed Naguib, the Islamic Union of Kurdistan, headed by Muhammad Faraj Ahmed", which have become the two major parties competing, whether in local elections in the province, or in the federal parliamentary elections ${ }^{4}$.

\section{Minority Lists}

Iraqi minorities "Christian and Yazidi and Sabean Mandaean" contributed 13 electoral lists, distributed to

\footnotetext{
${ }^{1}$ See: Ibraheem Alhaidari, op. cit., p. 276.

2 See: The Electoral Commission, for each province, ballot papers, op. cit.

3 The breakdown is seen: the Electoral Commission data, op. cit.

${ }^{4}$ See: Electoral Commission data for the outcome of the parliamentary elections, provincial councils, and the Kurdistan Region.
} 
all Iraqi provinces; the elections under Iraq Act made Iraq one constituency listing the components of Iraq ${ }^{5}$ and each had their own party that represents them and demands their rights, at all social, political, economic, and cultural levels.

Looking at the electoral map in Iraq, which is a reflection of the behavior of the electoral groups consisting of the Iraqi people, we find that the Iraqi voter did not interrupt a long way in overcoming sectarianism, by virtue of social historical influences, and political, economic, and security that accompanied the Iraqi men since the establishment of the modern Iraqi state and kissed her. And voting behavior in Iraq remains ethnically - sectarian in its entirety. After analyzing the results of the elections, we have reached a number of indicators including:

On the Level of electoral lists, we find that they are factional lists par excellence (sectarian and ethnic), and it is often limited to the candidates of a particular social component. But it contained some candidates from other components; it shall be for decoration, to market itself as superior to it.

The restraint of most electoral lists for participating in confined circles on the ethnically diverse social component did not see, for example, the descent of the Sunni lists in the southern provinces, Shiite majority or Shiite lists in Anbar province, and Arab lists in the province of Kurdistan, and vice versa.

List of the National Coalition led by Ayad Allawi, which marketed itself on a national basis and was not factional, did not get any representation at all classified Shiite provinces, with the exception of one seat in the province of Babylon. While we got a clear representation in Senyh provinces, in the 2010 elections, the list of Ayad Allawi got in the Shiite provinces nearly 13 seats when it was called the Iraqi List, at the time ${ }^{6}$. One reason may be the lack of access of any Shiite lawmakers in that list to any executive position in the previous government. What led them to get out of the Iraqi list and the formation of what is known as the white mass fought in the last election but did not get any seat. This election also indicated the rise of local forces, reflecting the local reality of certain electoral circle, and purpose does not exceed this circuit, as well as another type of electoral lists, which are active in the categorical framework and wider than constituency, such as the political forces and entities that are active in provinces Anbar, Diyala, and in the Central Euphrates provinces, or otherwise, which is in its entirety tribal forces who have brought their children to win elections.

Consolidating the phenomenon of the impact of the code (charisma) of some personalities, political leaders. Figure Prime Minister "Nouri al-Maliki", who won first place in the number of votes obtained by all candidates in all electoral lists won 721,782 votes, out of 1,074,609 votes for the destruction of the rule of law, what accounted for almost $69 \%$ of the total votes of the coalition. Of the total votes in Baghdad province, it amounted to 2,821,919 votes ${ }^{7}$.

And Ayad Allawi, who came in second place, won in Baghdad on 229,709, of the total votes of the National Coalition, led by the 348,205 votes. Elections also noted that the voting behavior of a large segment, perhaps the largest in the Iraqi society did not depart from the influence of sectarian and ethnic factionalism, as well as the impact of personalism, without much attention to the programs of the electoral lists competing. Lead to reproduce the same ruling political blocs' production, with some changes in the electoral weights. In this context, there has become a clear trend towards the emergence of an electoral map across regions and groups of Iraq. So it has become a common expression of some of the social division dimensions, which have a role in the

\footnotetext{
${ }^{5}$ See: Iraqi Council of Representatives elections law no. 45 for the year 2013.

6 See: The Electoral Commission, the results of the parliamentary elections in 2010.

7 See: Electoral Commission data, op. cit.
} 
structure of power and political parties, lists, electoral trends through the expression of geographical areas and ethnic components, or what is called by the media. It is a result of the policies of the political regimes that came to rule Iraq, dedicated to the engineering of these divisions, through discrimination practiced against the Iraqi social groups' policies, as well as the impact of the US occupation of Iraq and the resulting political process, built on the basis of social components, or what is known (to democracy harmonic), and not on the national common basis. But that does not mean that the Iraqi voter's behavior did not develop despite numerous electoral experiences fought since 2005 , and this is what will be seen in the third section of this study.

\section{The Second Topic: Political Awareness and Political Participation}

Iraq has witnessed, an important political shift on September 4, 2003, and large-imposed political transition process, from the one-party system to a democratic system based on political pluralism and partisan. And there have been a number of electoral processes, parliamentary and local, and dashed civil activity across a wide range of organizations that deal with humanitarian areas, and economic, social, and cultural variety. Iraq also witnessed a significant media transformation in terms of opening the door and press pluralism, space stations, radio $^{8}$, and the entry of individuals on the Internet and the accumulation of elections to get awareness in the mind of the individual Iraqi or accustoming citizens to exercising the elections properly (Mousaad, 2008, p. 106).

\section{Political Awareness}

Awareness is described as "emotional charge viscerally powerful, lies in the many aspects of the behavior of the individual". They are made up of consciousness, through the stages of educational work, in various stages of education, the more you have mature and stable consciousness, the more likely it is to support and guide behavior in the desired direction (Allekani, 1999, p. 204).

And awareness as well is the "perception and understanding of the alert and at the same time the outside world, and for social belonging, and results from meditation to the world, substantive work and social action in all its aspects". This leads awareness to take individual positions and collective process that the awareness is linked to behavior; also, the language plays an important role in the awareness.

The psychology uses the term feeling (Kayali, 1994, p. 295). This means that the awareness is of a state of mind, is to recognize the rights of the world in a mental or sentimental way; the person knows a variety of forms of the awareness, religious, political, and scientific awareness, moral consciousness. In this sense, we can say that the political consciousness "is a situation where an individual or member of the community is the political life of various dimensions issues, and these issues have taken a cognitive and emotional attitude at the same time" (Assadwatfa, 2003, p. 70).

Definition of political consciousness is as "a set of values and trends and political principles, which allows an individual to actively participate in the conditions of society and its problems: community analyzed, judged, and determined the position of them, in order to develop them and change them" (Allekani, 1999, p. 204). The increase in the number of learners, the evolution of the field of education, the proliferation of media, and increasing political awareness develop political demands and increase the political participation (Huntington, 1993, p. 12). When individuals become politically conscious, they can overcome their own problems, which

\footnotetext{
${ }^{8}$ Media shifts appeared, in the growing and diverse number of newspapers, which reached nearly 203 newspapers and magazines, but their number was soon dropped to about 56 newspapers, and nearly 100 media outlets. See: Democracy Watch, democratization in Iraq, the Iraqi institute report, the first report (2010-2012).
} 
relate to their interests with the community, and can recognize the strength and ability of themselves, interdependent with others to address the general problems and work to resolve them, or the development of new programs for the process of political, social, economic, and cultural work within the society (Kayali, 1994, p. 295). While the lack of political awareness represents a state of weightlessness, the confusion and chaos in many walks of life have to be disciplined and systematic to facilitate people's lives, and reach the ultimate goal of the policy, which take care of the interests of the people (Kayali, 1994, p. 95). This is what we might call the intellectual and political infiltration of others, affecting the various plans of the state and spreading chaos among the members of the community and between the community and the political power. In this society preoccupied with political battles instead of building and development of the country, from here, it begins a loss of confidence in the government and political power, losing confidence in the society as a whole and dispersing to become the conflicting parties. It produces chaos and social and economic disaster. The formation of the political awareness is the first phase of political participation, ranging from political attention to the political knowledge, and then the political vote, and finally political demands (Yosef, 2001, p. 72) and a high level of community awareness; the dimension of the political circumstances, economically and socially, is one of the basic requirements to participate actively in the electoral processes. Based on the above, it can gain awareness through knowledge and means of formation of public opinion, government institutions and non-governmental organizations such as trade unions, or private associations, unions, and political parties, and through frequent participation in electoral processes, whether local or parliamentary.

\section{Political Participation}

It is an important factor in consolidating the awareness and the development of the electoral behavior and voluntary work and building the young generations. Participation is a process carried out by an individual or a group of independent free will in the formulation of political life styles and community, in the community in which he lives. And it has multiple areas, including labor and partisan lobbyists. The most important means of participation "is issued by the citizen's right to vote in elections and public referendums, and in which governments are working to maintain the protection of this right in line with democratic methods" (Awad, 2010, p. 389).

Iraqi constitution of 2005 has passed, clearly that participation is one of political rights, which should not deprive any citizen of them because of their nationality or ethnicity, also approved that the principle of popular sovereignty as a principle is based upon the right to contribute to the public interest ${ }^{9}$. The most prominent forms represented by the political participation in general are voting in elections, the nomination of the electoral boards, participation in the electoral campaigns of the candidates, and participating in other activities related to the local community.

Broad participation in the elections depends on several factors, including:

(1) Neutrality and forgery: If the election neutrality will increase the participation rate, the forgery will decrease in the rate of participation in the elections ${ }^{10}$;

\footnotetext{
9 Terms of Article 20 of the Constitution provide "citizens, men and women the right to participate in public affairs and to enjoy political rights, including the right to vote and run as candidates". Also Article (5) on "The law is sovereign; the people are the source of authority and legitimacy, exercised through direct, secret ballot and through their constitutional institutions". See: Iraqi constitution in force for 2005, materials (20) and (5).

${ }_{10}$ Article (20) of the Constitution provides "citizens, men and women the right to participate in public affairs and to enjoy political rights, including the right to vote and run as candidates". Also Article (5) on "The law is sovereign; the people are the source of authority and legitimacy, exercise through direct, secret ballot and through their constitutional institutions". See: Iraqi constitution in force for 2005, materials (20) and (5).
} 
(2) Social environment: A large proportion of the voters are affected by the social environment in which they live and affect family and neighbors, if they follow the environment of the clan (Salem, 2011, p. 191);

(3) Economic situation: Voters will vote to parties that claim to improve their standard of living in communities that suffer from unemployment and poverty. Residents vote to those calling for economic improvement and the rich vote for conservatives (Alduekat, 2002, p. 323). Thus, it can be interpreted in economic conditions and the living situation of the Iraqi voter percentage of voting patterns;

(4) Characteristics of the candidate or electoral list: There is no doubt that the personal qualities of the head of the electoral list or the candidate impact on the voting pattern. Often, voters vote in favor of a particular party list, because of the strength of that party, or that side. Can the personal qualities of the candidate on the voting trends affect voters (Dovreign, 2011, p. 105)?

(5) As well as those factors, there are other factors relating to the impact of the media, in addition to age, sex, and level of scientific knowledge and the electorate.

And thus, participating in the political process, whether the nomination or voting or election campaigns, the most prominent forms of political participation in Iraq reflect the most important indicators of analysis in this study.

(1) Size filtration rate and compete for the seat parliament: the nomination size, rate of electoral competition for the seat of parliament, both at the constituency level, or at the national level; one of the indicators over the electorate reaction with the electoral process on the one hand, and the impact of the elections on the evolution of the particle electoral awareness, on the other hand. Participation rates have exceeded to run in the parliamentary elections of 2014. Table 1 showed all participation rates in all elections in 2014, where the total number of candidates reached 9,039 candidates. You can identify the level of development in the Iraqi citizens' voting behavior by comparing rates of participation with previous elections. In the National Assembly elections on January 30, 2005, the total number of candidates $(7,761)$ competed for 275 seats for the National Constituent Assembly, while the total number of candidates stood in the House of Representatives elections on December 15, 2005 was 7,655 candidates (Independent Electoral Commission, 2006, pp. 1-7).

While in the parliamentary elections of 2010, the number of candidates fell to 6,234 candidates.

In this connection, it can be referred to a marked contrast to the rate level of competition on the single-seat in different constituencies. The last session reflected high rates for some constituencies, especially the province of Baghdad, the highest rate rose to compete 365 candidates/seat. It is a very high rate, while recorded provinces (Dohuk and Sulaymaniyah) had the lowest competition for the single-seat to compete eight candidates per seat.

(2) Participation at the general level:

It has resulted from participating in the parliamentary elections of 2014 which, among other indicators to measure participation rates may be controversial; it is $36,859,907$ which are the citizens of the total number of the population in Iraq ${ }^{11}$. There were almost 20,091,396 of those who were eligible to participate in the elections according to the records of the Electoral Commission, and in return it has received a total of 17,179,718 votes, a citizen of the voting card to vote, by $85.35 \%$, and the Commission has distributed 934,769 cards for votes, by 92.63\%. The total distributed cards for public and private voting card were $18,114,487$, by $85.73 \%$ (Independent Electoral Commission, 2014, p. 67). This reflects an unexpected major recording, which can be

11 The population is taken, according to data from the Ministry of Commerce to the Muslim Independent Electoral Commission. 
explained by the activity and large government propaganda that is explained by Electoral Commission's efforts, to push citizens about the need to review the registration centers, through direct contact or the varied media, and through mosques and Shiite mosques, and the efforts of civil society organizations, which raise the level of awareness among the community. But the proportion of the voting public was not the level of interest shown by voters in the registration phase (phase of voter registration update). But that does not underestimate the proportion of the public vote; they were good percentage according to international standards that deal with electoral affairs. The percentage of registered voters, according to the number reached almost total voters (62\%), while percentage of voters reached by the number of recipients of the voter's card was almost $73.54 \%$, which is the actual percentage of them as the right to vote is the voter who owns an electoral card. By looking at Table 2, we can divide the Iraqi electoral districts, according to the voting percentages into several categories:

Table 1

Competitive Rate on General Seats in Different Constituencies in 2014

\begin{tabular}{lllllll}
\hline The province & Number of seats & $\begin{array}{l}\text { The number of } \\
\text { candidates }\end{array}$ & Male & Female & $\begin{array}{l}\text { The number of } \\
\text { competing entities }\end{array}$ & $\begin{array}{l}\text { Competition for } \\
\text { electoral seat rate }\end{array}$ \\
\hline Baghdad & 69 & 3,309 & 2,323 & 986 & 43 & 365.95 \\
Basra & 25 & 776 & 560 & 216 & 25 & 31.04 \\
Maysan & 10 & 204 & 150 & 54 & 14 & 20.4 \\
Qadisiyah & 11 & 394 & 282 & 112 & 21 & 35.81 \\
Dhi Qar & 19 & 652 & 472 & 180 & 23 & 34.31 \\
Najaf & 12 & 303 & 221 & 81 & 18 & 25.25 \\
Muthanna & 7 & 158 & 114 & 44 & 12 & 22.57 \\
Karbala & 11 & 306 & 221 & 85 & 18 & 27.81 \\
Babil & 17 & 572 & 412 & 160 & 20 & 21.21 \\
Diyala & 14 & 297 & 210 & 87 & 17 & 18.2 \\
Anbar & 15 & 273 & 191 & 82 & 13 & 37.63 \\
Wasit & 11 & 414 & 297 & 117 & 22 & 8.09 \\
Dohuk & 11 & 89 & 62 & 27 & 7 & 9.33 \\
Arbil & 15 & 140 & 99 & 41 & 9 & 8.61 \\
Sulaymaniyah & 18 & 155 & 110 & 45 & 7 & 18.91 \\
Saladin & 12 & 227 & 163 & 64 & 13 & 26.16 \\
Kirkuk & 12 & 314 & 226 & 88 & 20 & 14.74 \\
Nineveh & 31 & 457 & 322 & 135 & 16 & \\
Total & 320 & 9,039 & 6,435 & 2,604 & 318 & \\
\hline
\end{tabular}

Note. Table of the work of researchers is based on the Independent Electoral Commission data.

(a) First category (44-54\%). It includes the provinces (Anbar, Baghdad-Karkh, and Nineveh); this category included the province of Baghdad with a heavy population and large election where the number of inhabitants is $8,291,631$, according to data from the Ministry of Commerce, the total number of voters is almost 4,904,058 voters. The number of seats with the minority seats is 71 seats. It represents more than a quarter of voters in all the provinces. But we see a decline in percentage of the number of voters (53.5\%) who affected the relative weight of the value of the default electoral seat in Baghdad by 68,990 votes, while in Diyala province, 38,411 votes, smaller compared with other provinces ${ }^{12}$. The security confusion of the provinces of Anbar and Nineveh

\footnotetext{
${ }^{12}$ Note that the number of votes per seat is at least lower than the rate of participation in the elections, as the access to the seat is becoming increasingly difficult as the participation rate rose, and vice versa, the lower the participation rate is, the less the number of votes required to get a seat. Thus contributing to the rise of the candidates may not represent the true will of the voters.
} 
that they experienced may be the influential factor in small percentage of the voting in them, especially Anbar province;

(b) The second category (57-62\%), which includes four constituencies (Saladin, Maysan, Diyala, and Basra);

(c) The third category (65-69\%) has five provinces (Dhi Qar, Muthanna, Kirkuk, Karbala, and Babil);

(d) The fourth category (70-76\%) has six constituencies (Wasit, Qadisiyah, Arbil, Sulaymaniyah, Dohuk, and Najaf).

Table 2

Percentage of Participation of the Iraqi Provincial Elections in 2014 to Vote (Public and Unconditional)

\begin{tabular}{|c|c|c|c|c|c|c|c|c|}
\hline Sequence & The province & $\begin{array}{l}\text { The number } \\
\text { of registered } \\
\text { voters }\end{array}$ & $\begin{array}{l}\text { Number of } \\
\text { voters }\end{array}$ & Turnout & $\begin{array}{l}\text { Number of } \\
\text { seats }\end{array}$ & $\begin{array}{l}\text { Number of } \\
\text { recipients } \\
\text { voter card }\end{array}$ & $\begin{array}{l}\text { The number } \\
\text { who voted }\end{array}$ & $\begin{array}{l}\text { Percentage of } \\
\text { turnout }\end{array}$ \\
\hline 1 & Baghdad-Rusafa & $2,762,973$ & $1,593,988$ & $58 \%$ & 71 & $2,335,323$ & $1,592,222$ & $68 \%$ \\
\hline 2 & Baghdad-Karkh & $2,141,085$ & 787,293 & $49 \%$ & & $1,764,827$ & $1,052,463$ & $60 \%$ \\
\hline 3 & Basra & $1,611,794$ & $1,006,728$ & $62 \%$ & 25 & $1,287,484$ & $1,001,680$ & $78 \%$ \\
\hline 4 & Maysan & 605,031 & 351,396 & $58 \%$ & 10 & 501,900 & 351,603 & $70 \%$ \\
\hline 5 & Qadisiyah & 662,708 & 475,602 & $71 \%$ & 11 & 602,531 & 473,494 & $79 \%$ \\
\hline 6 & Dhi Qar & $1,075,824$ & 707,013 & $65 \%$ & 19 & 906,875 & 697,497 & $77 \%$ \\
\hline 7 & Najaf & 768,519 & 546,737 & $75 \%$ & 12 & 677,580 & 535,063 & $79 \%$ \\
\hline 8 & Muthanna & 419,471 & 276,070 & $66 \%$ & 7 & 358,686 & 276,348 & $77 \%$ \\
\hline 9 & Karbala & 617,846 & 427,470 & $69 \%$ & 11 & 548,064 & 426,107 & $78 \%$ \\
\hline 10 & Babil & $1,041,989$ & 723,618 & $69 \%$ & 17 & 946,340 & 721,057 & $76 \%$ \\
\hline 11 & Anbar & 531,067 & 381,454 & $44 \%$ & 15 & 429,344 & 393,812 & $92 \%$ \\
\hline 12 & Wasit & 690,566 & 483,440 & $70 \%$ & 11 & 619,993 & 483,440 & $78 \%$ \\
\hline 13 & Dohuk & 612,059 & 469,044 & $76 \%$ & 11 & 559,636 & 465,718 & $83 \%$ \\
\hline 14 & Arbil & 971,196 & 712,369 & $73 \%$ & 15 & 845,399 & 713,294 & $84 \%$ \\
\hline 15 & Sulaymaniyah & 116,8461 & 862,458 & $74 \%$ & 18 & 985,702 & 859,868 & $87 \%$ \\
\hline 16 & Saladin & 769,572 & 435,226 & $57 \%$ & 12 & 657,639 & 435,226 & $66 \%$ \\
\hline 17 & Kirkuk & 841,297 & 574,421 & $68 \%$ & 12 & 753,828 & 568,660 & $75 \%$ \\
\hline 18 & Nineveh & $1,912,447$ & $1,036,233$ & $54 \%$ & 31 & $1,573,140$ & $1,034,290$ & $66 \%$ \\
\hline 19 & Diyala & 887,491 & 537,757 & $61 \%$ & 14 & 804,998 & 537,757 & $67 \%$ \\
\hline Total & & $20,091,396$ & $12,388,317$ & $62 \%$ & 328 & $1,7159,289$ & $12,619,599$ & $73.54 \%$ \\
\hline
\end{tabular}

Note. The table has been prepared based on the Independent Electoral Commission data.

Voter turnout varied from one province to another. The urban districts, such as the province of Baghdad were less fortunate than rural counterparts, in the turnout. It got the same rural character circuits (clan) to demand higher rates such as Muthanna, Qadisiyah, Dhi Qar, Najaf, and Karbala. The proportion of voters has made to recipients about voter cards (77\%) in Muthanna, about 79\% in Najaf and Qadisiyah, and 77\% in Dhi Qar. While the share of Baghdad was low when we compared it with rest of the other provinces as the proportion of the vote recorded $(53.5 \%)$ at a general level, and about $64 \%$ of voters attributed to the recipients of voter cards. The rates in the rest of the Arab provinces orbiting these numbers are shown in Table 2.

As for the provinces of Kurdistan Region (Arbil, Sulaymaniyah, and Dohuk), they have maintained their lead in turnout both at the general level and at the level of turnout to the ratio of the number of recipients of 
voter cards. These ratios reflect the group important indicators regarding the role of the tribes, who appeared enabled in every election cycle, including the latest (2014), which have different dimensions and implications on the general framework of the Iraqi parliament. And the mechanisms used by the members of parliament to achieve the interests of their citizens, which have become just the demands of service to different regions and departments, as well as the nature of the electoral system, allow the registration and nomination and polling in the place of birth and place of residence according to the ration card.

\section{The Third Section: Variation Rate of Participation in Elections (2005-2010-2014)}

The study of the level of voter's participation in the elections is one of the issues that concerned awareness of the electoral meeting, and political psychology, as well as knowledge of geopolitics. And we can measure by the level of competition between electoral entities. They express the social level and the political level, especially if there is more electoral experience to be comparison. Comparing it with the previous elections, specifically the two sessions of the year 2005 and the year 2010, we can record a number of comments through the study of the variation in the rate of participation at the level of each constituency, as shown in Tables 3, 4, and 6.

(1) Baghdad (the capital): It is one of mixed sectarian districts ethnically and religiously, as well as it contains a variety of economic classes. In spite of its small size, Baghdad represents the largest electoral weight of all the other Iraqi provinces which are containing the highest number of voters $(4,904,058)$, a rate $24.2 \%$ from the registered voters in Iraq. But note the low rate of participation in the vote in 2014 elections; it is from $70 \%$ to $53.5 \%$, which is almost identical with the percentage of the vote in the 2010 elections. It did not increase by only $1 / 2 \%$ (Independent Electoral Commission, 2014, p. 68).

(2) Nineveh: Characterized by ethnic diversity (religious, nationalist, and sectarian), it is the second constituency in terms of the electoral weight and the number of seats is assigned to it. The number of voters $(1,912,447)$ makes up $9.5 \%$ of the total registered voters. But in spite of changes in the number of voters for what it was like in the 2010 elections, it increased by 209,486 voters. However, the percentage of the vote had fallen from $70 \%$ to $66 \%$ to $54 \%{ }^{13}$ in the elections of 2014 , in the presence of national competition clearly listed among Arab, Kurdish, and Turkmen, as signs of a possible impact of the bad security conditions on the behavior of Muslin voter, especially before the elections.

(3) Basra: It is the third place by population and is the only Iraqi port on the Gulf, considered as one of the richest provinces for containing the largest amount of the oil reserves and oil production. But a large proportion of its population are living in poverty, unemployment, and poor services, which may be reflected in the participation rate which, despite increasing the number of registered voters $(1,611,794)$, represents the ratio $(8 \%)$ of the total number of voters in Iraq. The percentage of the vote in 2014 elections was $62 \%{ }^{14}$, higher than the rate of participation in $2010(57 \%)$, and less than the participation rate in $2005(74 \%)$, which was a good proportion in general.

(4) Maysan: This constituency does not differ from other constituencies in the high proportion of participants. The participation rate increased to $73 \%$ in 2005 , but it soon fell to $50 \%$ in the 2010 elections, and soon rose to $58 \%$ in the election cycle in 2014 , which could be attributed to the development of services if compared to other southern provinces.

\footnotetext{
${ }^{13}$ See: Electoral Commission data, the source previously mentioned.

14 The Electoral Commission data for the elections, op. cit.
} 
(5) Qadisiyah: It is a Euphrates province of east constituency which is characterized by a tribal nature; the percentage of the vote was not high in the 2005 elections where it was $64 \%$, and then dropped in 2010 elections to $62 \%$ despite the increase in the number of voters. While in the last election in 2014 , it indicated a clear increase in the participation rate $(71 \%)^{15}$ after the number of voters rose to 662,708 voters, which is a very good percentage when compared to other provinces.

(6) Dhi Qar: It is one of the southern provinces that are similar in social and tribal structure, classified as one of the arenas of competition between the forces and the Shiite electoral lists. The number of voters has increased to $1,075,824$, increasing the proportion of voting to $65 \%{ }^{16}$ in the last election, after dropping in the 2010 to $60 \%$ from the previous cycle of 2005 (71\%).

(7) Najaf: It is one of the provinces with sacredness to the majority of the Iraqi people; it is also the headquarters of the most prestigious Shiite - the Hawza, and the residence of the supreme religious authority-Ali al-Sistani, who had a large role to influence the electorate in the province and other Iraqi provinces. The recorded highest voter turnout was $75 \%$, after the number of voters has increased to $768,519^{17}$, which was the highest rate for that district during the three sessions.

(8) Muthanna: It is one of the southern provinces characterized by a lack of population and therefore the number of voters in which registered in the 2014 elections was 419,471 voters, a slight increase in the participation rate recorded (66\%), after it had been in the 2005 elections (66\%), and 2010 (61\%), respectively. It is a good ratio when compared with other constituencies ${ }^{18}$.

(9) Karbala: It is a constituency as one of the strongholds of the Shiite parties and Islamic forces. It has registration of good ratios of participating in elections since the 2005 elections, $70 \%$ in $2005,75 \%$ in 2010 , and $69 \%$ in 2014, sequentially. Here, that reveals religious establishment's impact on the voting behavior in that district.

(10) Babil: It is one of the Central Euphrates provinces, predominantly Shiite, although the northern areas of it have a sectarian diversity. The number of voters increased to $1,041,989$ in the 2014 elections, and came to the percentage of participation $69 \%$, from $63 \%$ in the 2010 elections. It is a very good rate ${ }^{19}$.

(11) Wasit: The participation in that district has decreased during the parliamentary elections in 2010 to $60 \%$, lower than the rate achieved in the 2005 elections $(68 \%)$. It was able to register an increase in the parliamentary elections in 2014 , which reached $70 \%$, after the increase in the number of voters to $690,566^{20}$.

(12) Anbar: It is one of the western provinces of Iraq, heterogeneous, nationalist, and sectarian (Sunni Arab), with a tribal nature, as is the case in all provinces of Iraq where the influence of tribal leaders is great for the small number of the population according to Ministry of Commerce statistics for the year 2013, which is $1,680,084$ people. The number of voters stood in the parliamentary elections in 2014 is 531,067 , while the participation rate was $44 \%$, which was the lowest participation rate among all other Iraqi provinces, after the percentage of the vote in the 2005 parliamentary elections that was $86 \%$. The reason for this high percentage was because of their sense of political grievance after the low percentage of participation in the National

\footnotetext{
15 The Electoral Commission data for the elections, op. cit.

16 The same source.

17 The same source.

18 The same source.

19 Independent Electoral Commission data.

20 The previous source.
} 
Assembly elections, which amounted to $2 \%$ only. But quickly, it fell to $61 \%$ in the 2010 elections. Since that province suffered continuously from confusion in the security file, and suffered from the presence of armed groups with the trends toward disparate goals, it clearly affected the attitudes of the voters and led a large proportion of them to abstain from participating in the elections. If we followed those participation rates of the constituency, since the National Assembly elections and the referendum on the constitution, it shows a ratification of the constitution in a referendum in 2005 by $97 \%$. The percentage of voice for yes to the constitution is only $3 \%^{21}$.

(13) Saladin: It is one of the constituencies, but with ethnic diversity (national and sectarian), which was characterized during the parliamentary elections in 2005 and 2010, with a high rate of participation from $98 \%$ to $73 \%$. We find that it has declined in the recent elections to the $57 \%$ in spite of the increase in the number of registered voters $(769,572)$, which could be explained by the security deterioration of the province that was witnessed like the majority of other Sunni governorates ${ }^{22}$.

(14) Diyala: It is characterized by the diversity of other nationalist and sectarian, witnessing security disturbances in a row, as a result of the presence of armed groups. After that, the participation rate recorded relatively high (74\%) in the 2005 elections, but it quickly fell to $62 \%$ in 2010 and to $61 \%{ }^{23}$ in the last election.

(15) Dohuk: It is one of the northern provinces, affiliated to the Kurdistan Region, heterogeneous nationally, with some minorities like Christians. It rated with high participation rates since the 2005 elections, and the percentage recorded was $92 \%$, and $80 \%$ in 2010 . However, soon the proportion of the participation in the elections of 2014 dropped to $76 \%$, although there was the increase in the number of voters $(612,059)^{24}$. But it remains classified as a high participation rate in constituencies.

(16) Arbil: It is capital of Kurdistan province, and stronghold of President of the Democratic Party of Kurdistan. The number of voters increased to the 971,196 , but the percent of turnout recorded $73 \%$ in the last election, which was less than that in the 2005 elections (95\%), and in the 2010 elections $(76 \%)^{25}$.

(17) Sulaymaniyah: It is one of the big northern provinces of Kurdistan Region, and historically one area of influence of the Kurdistan National Party, headed by Jalal Talabani. Until the 2010 elections, until the rise of the Goran/Change party, headed by Nshiroan Mustafa, it is one of high participation provinces. After that, the number of voters has increased to $1,168,461$, and the percent of turnout was $74 \%$, after it had been $73 \%$ in 2010 , which was a very good rate despite the decline from the 2005 elections $(86 \%)^{26}$.

(18) Kirkuk: It is one of the important Iraqi provinces in terms of ethnic diversity, and its large oil reserves and output, the constituency has long seen great political rivalry between the forces and Kurdish parties on the one hand, and the Arab and Turkmen on the other hand. Since the 2005 elections voting reached, the proportion of the participation was $86 \%$, then $73 \%$ in the 2010 elections, and $68 \%$ in the elections of 2014 , despite an increase in the number of voters to $841,297^{27}$.

\footnotetext{
21 The Electoral Commission data for the elections, op. cit.

${ }^{22}$ See: Electoral Commission data, the source previously mentioned.

23 The same source.

${ }^{24}$ See: The Electoral Commission data, the source previously mentioned.

25 The same source.

26 The same source.

27 The same source.
} 
Table 3

The Rate of Participation in the 2005 Elections

\begin{tabular}{llllll}
\hline Number of seats & Turnout & $\begin{array}{l}\text { The relative weight } \\
\text { for each seat }\end{array}$ & $\begin{array}{l}\text { The number of } \\
\text { voters }\end{array}$ & $\begin{array}{l}\text { The number of } \\
\text { voters }\end{array}$ & The province \\
\hline 59 & $70.10 \%$ & 44,778 & $2,702,541$ & $3,857,499$ & Baghdad \\
19 & $70.20 \%$ & 48,555 & 942,514 & $1,343,381$ & Nineveh \\
16 & $74.20 \%$ & 50,170 & 813,758 & $1,096,749$ & Basra \\
15 & $86.10 \%$ & 53,302 & 809,759 & 961,786 & Sulaymaniyah \\
13 & $95.30 \%$ & 62,797 & 828,810 & 870,026 & Arbil \\
12 & $71.90 \%$ & 48,552 & 588,415 & 818,939 & Dhi Qar \\
11 & $79.40 \%$ & 53,067 & 593,828 & 747,588 & Babil \\
10 & $74.90 \%$ & 51,961 & 529,755 & 707,598 & Diyala \\
9 & $86.10 \%$ & 65,070 & 595,425 & 691,581 & Kirkuk \\
9 & $86.40 \%$ & 64,408 & 585,429 & 677,821 & Anbar \\
8 & $98.40 \%$ & 67,810 & 555,755 & 564,607 & Saladin \\
8 & $72.80 \%$ & 47,460 & 385,533 & 529,890 & Najaf \\
8 & $64.70 \%$ & 41,874 & 338,925 & 524,073 & Qadisiyah \\
8 & $68 \%$ & 43,831 & 354,563 & 521,466 & Wasit \\
7 & $92 \%$ & 59,707 & 422,218 & 458,924 & Dohuk \\
7 & $73.30 \%$ & 45,825 & 323,250 & 441,168 & Maysan \\
6 & $70.40 \%$ & 50,882 & 309,771 & 439,764 & Karbala \\
5 & $66.10 \%$ & 41,158 & 208,662 & 315,842 & Muthanna \\
230 & $76 \%$ & - & $11,888,911$ & $15,568,702$ & Total \\
\hline
\end{tabular}

Note. The table has been prepared based on the Independent Electoral Commission data.

Table 4

The Rate of Participation in the 2010 Elections

\begin{tabular}{llllll}
\hline Number of seats & Turnout & $\begin{array}{l}\text { The relative weight } \\
\text { for each seat }\end{array}$ & $\begin{array}{l}\text { The number of } \\
\text { voters }\end{array}$ & $\begin{array}{l}\text { The number of } \\
\text { voters }\end{array}$ & The province \\
\hline 68 & $53 \%$ & 37,198 & $2,529,440$ & $4,599,782$ & Baghdad \\
31 & $66 \%$ & 33,995 & $1,053,850$ & $1,702,964$ & Nineveh \\
24 & $57 \%$ & 33,950 & 814,804 & $1,466,512$ & Basra \\
17 & $73 \%$ & 49,037 & 833,631 & $1,098,451$ & Sulaymaniyah \\
14 & $76 \%$ & 48,600 & 680,408 & 917,685 & Arbil \\
18 & $60 \%$ & 31,606 & 568,900 & 993,372 & Dhi Qar \\
16 & $63 \%$ & 36,643 & 586,281 & 961,293 & Babil \\
13 & $62 \%$ & 48,684 & 502,896 & 840,241 & Diyala \\
12 & $73 \%$ & 32,420 & 557,037 & 787,673 & Kirkuk \\
14 & $61 \%$ & 40,722 & 481,878 & 802,378 & Anbar \\
12 & $73 \%$ & 34,268 & 411,217 & 696,913 & Saladin \\
12 & $61 \%$ & 33,939 & 373,339 & 696,599 & Najaf \\
11 & $62 \%$ & 34,265 & 376,910 & 619,862 & Qadisiyah \\
11 & $60 \%$ & 42,471 & 424,715 & 638,699 & Wasit \\
10 & $80 \%$ & 27,282 & 272,818 & 574,138 & Dohuk \\
10 & $50 \%$ & 33,343 & 333,434 & 561,742 & Maysan \\
10 & $75 \%$ & 32,714 & 229,000 & 364,691 & Karbala \\
7 & $61 \%$ & - & $11,499,226$ & $18,902,073$ & Muthanna \\
310 & $62 \%$ & Total & \\
\hline
\end{tabular}

Note. The table has been prepared based on the Independent Electoral Commission data. 
From the above, it can be concluded that the indicators of participation rates were over three consecutive election cycles, and did not occur significant changes, especially after the parliamentary elections in 2005. Although the general cycle (2014) brought about the political environment, according to many of the variables, it will meet the demand of modest turnout. But what happened is that they were not much different from previous sessions, and a special session of (2010) election, and then the participation rates were consistent, to a large degree with the indicators in the previous sessions. In addition to the above, it can be said that the weakness of political parties, the continued importance of inheritance organizations and ethnic sectarian dimension, and the weakness of the importance of parliament in political terms to citizens all may reflect reality, explaining the lack of escalation to participate in the voting rates, and survival within the intermediate levels or good at the general level and not very good or excellent. A number of reasons can be summed up for it.

(1) The weakness of political parties: Despite the presence of a large number of ideological parties, however, belonging to the party is still low; it is notable in most of the political parties in Iraq, with the exception of some of the forces and entities of partisan, Islamist, and nationalist (Shiite and Kurdish). It continues to suffer from the weakness of its ability to frame or influence public opinion, and the lack of its role in achieving political mobilization in general mass. Reflecting the weakness of the parties in this way, real trouble for these parties, and civil society organizations in modern Iraq was in its manifestations.

(2) The lack of a fan base in general and wide political parties (although it differs from the party to another) as the largest percentage of Iraqis does not belong to political parties.

(3) Weakness or the inability of the parties to influence public opinion, even though freedom of expression is available in Iraq after the change, but those parties are unable to develop the effective means in raising awareness and influencing public opinion, which has clearly demonstrated its inability to be a substitute for any traditional organization in the community.

(4) The continued strength of traditional organizations (clan): The clan has maintained as traditionally structured, on its ability to create the kind of mobilization in electoral processes; the clan became able to submit their nominations, and gather votes for them, and therefore they have ability to access to and influence on the decision-maker and push for their interests, by providing a framework to defend their interests and meet the demands of services and other (Alhaso, 1984, p. 45; Nadhmi, 1985, pp. 49-50). Thus, the clan has shown the ability to adapt to the democratic process and electoral rules, forcing parties and electoral lists to go about clans motivated to get their voices through the introduction of a number of its leaders or its members as candidates in the electoral lists.

(5) Double the importance of parliament among the electorates: There is no doubt that the presence of parliament representing the citizens can exert pressure to achieve their goals and different interests, and is one of the important issues in the political life of any society. More importantly, it is a degree of trust and conviction of citizens in the ability of this parliament to meet and achieve their goals and different interests, to reflect the importance of parliament also for the citizens of the extent of their faith to achieve political change in the country (Shatawe, 1997, p. 33). Through political events consecutive in Iraq, especially after the change, and the nature of the relationship is inconsistent to connect parliament with the government, and its inability to live up to the ambition of the citizens lead it to the descent of dissatisfaction with the performance of successive parliamentary sessions, which was reflected in turn on the level of participation of the electorate, and then the 
electoral behavior and the level of participation; there is the participation of women, which reflects the electoral behavior, voting, and filtration.

(a) Feminist participation:

The women in Iraq are characterized by low participation in the traditional formal political framework such as voting and nomination, and activities for the campaign. For political, cultural, and social nature reasons, they did not take their share of the active participation since the founding of the modern Iraqi state in 1921, until 2003. In royal era, women remained deprived of participation in the elections and vote the nomination ${ }^{28}$, the Republican era did not witness any actual electoral process until the issuance of the National Council Law No. 55 for the year 1980, when the first legislative election was held, but this did not increase the percentage of women's representation in all the sessions of the council $(10.8 \%)^{29}$. The interests of women were represented by a non-governmental organization for women called the General Federation of Iraqi Women, which is one of the Baathist regime tools. Further to that, it was women who are persecuted because of their political activity, or even political activities of their family members, especially if these activities are incompatible in any way with the ruling party orientations (Lawyers and the American Association of Magistrates, 2006, p. 19). Not only the political side, social factors play an important role in obstructing the participation of women in political life, especially in masculine societies; the dominant culture, which is the system of values and beliefs, practices and common trends for the group of people, affects their behavior and ways of thinking; and defining gender roles that are accepted by society for women and men, each according to sex, as well as the socialization, has a role in the formation of view to the site of women in society and political life (Alwaelly, 2012, p. 63). Iraqi society is masculine society and its view of women is that they are weak, and need a man to secure the necessities of life. And then social mental institution which is built on the norms and values of the clan did not favor political action for women, because this activity is violence and cruelty, making it difficult even to men due to the instability, and the rule of tyranny, in Iraq, as one of the Middle East unstable countries (Jawad, 2013, p. 6). After the change in Iraq and the transformation of the political regime from the dictatorial regime, "one-party system" to a pluralistic democratic system, the legislator resorted to a method to seek justice for the Iraqi women and ensure their representation in parliament by adopting a "quota" system. Those quotas were incorporated, and a former was not found in Iraq constitutionally and legally. They are stipulated by both the State Administration Law for the transitional period of 2004, and the Constitution of Iraq for the year $2005^{30}$, as well as the regulations issued by the Electoral Commission for elections in all electoral processes that have taken place since 2005. Women have participated in the National Assembly elections on January 30, 2005 as candidates and voted, and gotten 87 seats (275), almost 31\%. They had law-based proportional representation and the closed-list system, taking into consideration that Iraq is one electoral constituency. The woman did not win outside the quota despite large role in determining the share of women's representation in the National Assembly. In the parliamentary elections on December 15, 2005, the list remained closed and replaced by a single constituency legislator of multi-circuit system, by making each province according to its borders and

\footnotetext{
${ }^{28}$ See: Abdulrazaq Alhasany: Tareekh Aliraq Alseasy Alhadeeth. Part 1, part 10, op. cit. And see: Raad Naje Aljida Alta Shreeat Alinti Khabia Fi Aliraq, op. cit.

${ }^{29}$ See: Nahla Alnadawy: Al Adaa Al parlamany Lel Maraa Aliraqia. Matbaataltabaa, Baghdad, 2010, pp. 12-13.

30 See: Article 30 of the State Administration Law for the transitional period for 2004, Alwaqaee Aliraqia Newspaper, issue (3981), volume 45-2004. And paragraph (4), Article 49 of the Permanent Constitution of 2005, which provided for the election aimed to achieve a percentage of representation for women of not less than one quarter of the number of Members of Parliament Act.
} 
administrative electoral constituency. The share of women was 73 seats, accounting almost $26 \%$. While in the provincial elections of 2009, when it adopted the open list, four women won their seats without the quota. This was the first time that women get a seat without relying on the quota system. After the voters touch Iraqi women's ability to compete with men in the work to improve the services and development, women began to achieve high rates in their parliamentary representation without relying on the quota system, as was done in the parliamentary elections that took place on March 7, 2010. Woman managed to gain 21 seats, nearly 25\%, among the 82 winners who gained their seats without relying on the quota system and were distributed on 12 provinces (Baghdad, Dhi Qar, Babil, Nineveh, Basra, Arbil, Najaf, Wasit, Qadisiyah, Maysan, Dohuk, and Karbala). Baghdad had the largest share of eight women ${ }^{31}$. In the provincial elections in 2013, women wre able to get seven seats without the need for a quota, and the candidate (Aisha Ghazal Mehdi), who on the list is Muttahidoon received the highest votes $(11,420)$ collected in Baghdad province ${ }^{32}$. The increase in the number of women candidates in the parliamentary elections in 2014, which amounted to a total of 2,604 candidates, is the highest rate of women's nominations in all previous sessions, including the 2010 cycle in which the total candidates arrived 1,806; which indicates the high political awareness among Iraqi women and concerned by the need for their participation in political work, on the other hand reflects the importance given by the Iraqi legislature of the need for women to have an active role alongside men in the construction of the state and society. Despite the positives of this factor, it may have to pay a large number of women candidates to run in the elections without prior preparation.

(b) The level of the vote to women candidates:

Results relating to women candidates in the parliamentary elections of 2014 have shown that it has important consequences for women, both at the level of competition for the nomination, or voting rate, where 20 candidates got seats without the need for a quota, a rate $(24 \%)$ of the total 83 winners is women, who distribute on various constituencies and electoral lists. Candidate Hanan Saeed al-Fatlawi has topped from the list of Dawlat Alqanon in the province of Babil, by 90,781 votes superior to all the winning candidates of the men and women in that province. Looking at the candidates, the winners without cotta note that: the majority of whom come from deputies precedents, or are members of the provincial councils, which means that the voters know the candidate through activism featured on the level of employment in the legislatures of the previous cycles (such as Hanan al, and high Nassif, Najiba Najib Ibrahim, Alaa Talabani, and Sabah Abdul Rasul) (see Table 5). MP movement and activity in the social environment can not be overlooked, on the grounds that poor rule is broader in Iraqi society. The multiplicity of electoral processes has led to extend voter lists and electoral experience, which spurred many tribes to provide candidates and therefore the tribal principle tool did not impede women from contributing to the electoral process, particularly in the southern and central provinces where they may be motivated by materials such as huge salaries of the deputies and the privileges such as the moral prestige and social status (Jawad, 2013, pp. 92-93). But the most important factor remains, escalating awareness among women after the change, and the openness of the media and the Internet, and other political and social influences, as well as the growing conviction that Iraqi women after the change are able to contribute and participate to provide services and relieve the suffering inhabitants of region.

\footnotetext{
31 Electoral Commission data, op. cit. Retrieved: https://www.ihec.iq.com.

32 The same source.
} 
But the support of tribe to the women is not a quantum leap in mentally and behaviorally patriarchal clan that has nature of refusing to change attitudes towards women, and this phenomenon is beginning to change tribal values toward women, and in the repeated case for many cycles, the rule of law has enhanced the confidence of the women in the clan by themselves, which is possible to change behaviors and mental attitudes of men of the clan, because the masculine in the tribal values remains strong and not easy to change ${ }^{33}$.

Table 5

Winners Without Women Quota in the Parliamentary Elections in 2014

\begin{tabular}{|l|l|l|l|}
\hline The province & Political entity & Number of votes & Candidate name \\
\hline Babil & Dawlat Alqanon Coalition & 90,781 & Hanan Saeed Al Fatlawee \\
\hline Aldewania & Dawlat Alqanon & 39,691 & Hudaa Sajad Mahomood \\
\hline Dohuk & Kurdistan Democratic Party & 29,468 & Najeba Najeeb Ibraheem \\
\hline Diyala & Dyala Hawitona Coalition & 28,939 & Nahida Zaid Manhal \\
\hline Dohuk & Kurdistan Democratic Party & 17,574 & Shereen Abdulrahman \\
\hline Najaf & Dawlat Alqanon & 16,802 & Saad Jabbar Mohamma \\
\hline Arbil & Qoran Altageer & 14,229 & Sarwa Abdulwahed \\
\hline Diwaniya & Dawlat Alqanon & 14,011 & Seham Mossa Hamood \\
\hline Muthanna & Dawlat Alqanon & 9,312 & Khawla Manfi Jawda \\
\hline Sulaymaniyah & Kurdistan Democratic Party & 8,955 & Ashwaq Najimaldeen \\
\hline Babil & Alahrar Coalition & 8,661 & Zainab Thabit Kadom \\
\hline Baghdad & Dawlat Alqanon & 8,179 & Nada Abdulla Jassem \\
\hline Nineveh & Motahidoon Lelaslah & 6,588 & Intisar Ali Khider \\
\hline Baghdad & Dawlat Alqanon & 5,793 & Suaad Hameed Lafta \\
\hline Baghdad & Motahidoon Lelislaah & 5,454 & Aisha Gazal Mahdy \\
\hline Babil & Dawlat Alqanon & 4,453 & Lubna Raheem Kareem \\
\hline Kirkuk & Kurdistan Democratic Party & 4,455 & Alaa Tahseen Habeb \\
\hline Baghdad & Dawlat Alqanon & 4,079 & Nahida Hameed Lafta Jabor \\
\hline Baghdad & Dawlat Alqanon & 3,023 & Alia Nsaif Jasim \\
\hline Baghdad & Alwatania Coalition & 3,001 & Sabah Abdu lrasul \\
\hline
\end{tabular}

Note. Table of the work of researchers relies on Independent Electoral Commission data.

\footnotetext{
${ }^{33}$ The same source, p. 94 .
} 
Table 6

Details of Voters in the Parliamentary Elections in 2014

\begin{tabular}{|c|c|c|c|c|c|c|c|c|c|c|c|c|c|c|c|c|c|}
\hline $\begin{array}{l}\text { Total } \\
\text { percentages }\end{array}$ & $\begin{array}{l}\text { The } \\
\text { percentage } \\
\text { of births in } \\
1971\end{array}$ & $\begin{array}{l}\text { The } \\
\text { proportion of } \\
\text { births } \\
\text { between } 1972 \\
\text { and } 1995 \\
\end{array}$ & $\begin{array}{l}\text { Total } \\
\text { percentages }\end{array}$ & $\begin{array}{l}\text { The } \\
\text { proportion } \\
\text { of illiterate }\end{array}$ & $\begin{array}{l}\text { Literacy } \\
\text { rate }\end{array}$ & $\begin{array}{l}\text { Total } \\
\text { percentages }\end{array}$ & $\begin{array}{l}\text { The } \\
\text { proportion } \\
\text { of females }\end{array}$ & $\begin{array}{l}\text { The } \\
\text { proportion } \\
\text { of males }\end{array}$ & $\begin{array}{l}\text { The total } \\
\text { number of } \\
\text { voters was } \\
\text { born (1971) } \\
\text { or less }\end{array}$ & $\begin{array}{l}\text { The total } \\
\text { number of } \\
\text { voting among } \\
\text { baby boomers } \\
(1972-1995)\end{array}$ & $\begin{array}{l}\text { The total } \\
\text { number of } \\
\text { illiterate } \\
\text { voters }\end{array}$ & $\begin{array}{l}\text { The total } \\
\text { number of } \\
\text { voting } \\
\text { educated }\end{array}$ & $\begin{array}{l}\text { The total } \\
\text { number of } \\
\text { female } \\
\text { voters }\end{array}$ & $\begin{array}{l}\text { The total } \\
\text { number of } \\
\text { male voters }\end{array}$ & $\begin{array}{l}\text { The total } \\
\text { number of } \\
\text { voters who } \\
\text { voted }\end{array}$ & $\begin{array}{l}\text { The total } \\
\text { number of } \\
\text { voters }\end{array}$ & Province name \\
\hline $100 \%$ & $38 \%$ & $62 \%$ & $100 \%$ & $15 \%$ & $85 \%$ & $100 \%$ & $44 \%$ & $56 \%$ & 382,524 & 624,204 & 152,922 & 853,806 & 442,001 & 564,727 & $1,006,728$ & $1,611,794$ & Basra \\
\hline $100 \%$ & $40 \%$ & $60 \%$ & $100 \%$ & $26 \%$ & $74 \%$ & $100 \%$ & $43 \%$ & $57 \%$ & 139,250 & 212,146 & 90,873 & 260,523 & 152,811 & 198,585 & 351,396 & 605,031 & Maysan \\
\hline $100 \%$ & $34 \%$ & $66 \%$ & $100 \%$ & $20 \%$ & $80 \%$ & $100 \%$ & $47 \%$ & $53 \%$ & 162,156 & 313,446 & 97,283 & 378,319 & 222,227 & 253,375 & 475,602 & 662,708 & Qadisiyah \\
\hline $100 \%$ & $36 \%$ & $64 \%$ & $100 \%$ & $24 \%$ & $76 \%$ & $100 \%$ & $46 \%$ & $54 \%$ & 252,187 & 454,062 & 169,131 & 538,912 & 323,454 & 383,559 & 707,013 & $1,075,824$ & Dhi Qar \\
\hline $100 \%$ & $41 \%$ & $59 \%$ & $100 \%$ & $23 \%$ & $77 \%$ & $100 \%$ & $45 \%$ & $55 \%$ & 224,420 & 322,317 & 124,775 & 421,962 & 246,158 & 300,579 & 546,737 & 768,519 & Najaf \\
\hline $100 \%$ & $39 \%$ & $61 \%$ & $100 \%$ & $24 \%$ & $76 \%$ & $100 \%$ & $46 \%$ & $54 \%$ & 108,642 & 167,428 & 67,581 & 208,489 & 127,396 & 148,674 & 276,070 & 419,471 & Muthanna \\
\hline $100 \%$ & $32 \%$ & $68 \%$ & $100 \%$ & $45 \%$ & $55 \%$ & $100 \%$ & $35 \%$ & $65 \%$ & 510,557 & $1,083,431$ & 717,775 & 876,213 & 558,369 & $1,035,619$ & $1,593,988$ & $2,762,973$ & Baghdad-Rusafa \\
\hline $100 \%$ & $41 \%$ & $59 \%$ & $100 \%$ & $11 \%$ & $89 \%$ & $100 \%$ & $44 \%$ & $56 \%$ & 320,231 & 467,062 & 86,274 & 701,019 & 350,191 & 437,102 & 787,293 & $2,141,085$ & Baghdad-Karkh \\
\hline $100 \%$ & $41 \%$ & $59 \%$ & $100 \%$ & $11 \%$ & $89 \%$ & $100 \%$ & $45 \%$ & $55 \%$ & 176,384 & 251,086 & 46,889 & 380,581 & 193,571 & 233,899 & 427,470 & 617,846 & Karbala \\
\hline $100 \%$ & $37 \%$ & $63 \%$ & $100 \%$ & $27 \%$ & $73 \%$ & $100 \%$ & $43 \%$ & $57 \%$ & 266,693 & 456,925 & 191,844 & 531,774 & 314,662 & 408,956 & 723,618 & $1,041,989$ & Babil \\
\hline $100 \%$ & $32 \%$ & $68 \%$ & $100 \%$ & $25 \%$ & $75 \%$ & $100 \%$ & $43 \%$ & $57 \%$ & 170,408 & 367,348 & 132,253 & 405,504 & 229,956 & 307,801 & 537,757 & 887,491 & Diyala \\
\hline $97 \%$ & $34 \%$ & $62 \%$ & $97 \%$ & $4 \%$ & $93 \%$ & $97 \%$ & $33 \%$ & $63 \%$ & 131,601 & 237,718 & 15,939 & 353,380 & 127,127 & 242,192 & 381,454 & 531,067 & Anbar \\
\hline $100 \%$ & $41 \%$ & $59 \%$ & $100 \%$ & $18 \%$ & $82 \%$ & $100 \%$ & $47 \%$ & $53 \%$ & 200,179 & 283,261 & 85,542 & 397,898 & 225,401 & 258,039 & 483,440 & 690,566 & Wasit \\
\hline $100 \%$ & $37 \%$ & $63 \%$ & $100 \%$ & $31 \%$ & $69 \%$ & $100 \%$ & $51 \%$ & $49 \%$ & 172,533 & 296,511 & 147,458 & 321,586 & 237,069 & 231,975 & 469,044 & 612,059 & Dohuk \\
\hline $100 \%$ & $40 \%$ & $60 \%$ & $100 \%$ & $4 \%$ & $96 \%$ & $100 \%$ & $60 \%$ & $40 \%$ & 281,914 & 430,455 & 26,500 & 685,869 & 426,127 & 286,242 & 712,369 & 971,196 & Arbil \\
\hline $100 \%$ & $37 \%$ & $63 \%$ & $100 \%$ & $27 \%$ & $73 \%$ & $100 \%$ & $49 \%$ & $51 \%$ & 318,228 & 544,230 & 229,541 & 632,917 & 423,355 & 439,103 & 862,458 & $1,168,461$ & Sulaymaniyah \\
\hline $99 \%$ & $32 \%$ & $66 \%$ & $99 \%$ & $14 \%$ & $85 \%$ & $99 \%$ & $33 \%$ & $66 \%$ & 140,207 & 288,684 & 59,222 & 369,669 & 143,107 & 285,784 & 435,226 & 769,572 & Saladin \\
\hline $100 \%$ & $41 \%$ & $59 \%$ & $100 \%$ & $12 \%$ & $88 \%$ & $100 \%$ & $13 \%$ & $87 \%$ & 238,300 & 336,121 & 68,036 & 506,385 & 74,990 & 499,431 & 574,421 & 841,297 & Kirkuk \\
\hline $100 \%$ & $40 \%$ & $60 \%$ & $100 \%$ & $21 \%$ & $79 \%$ & $100 \%$ & $38 \%$ & $62 \%$ & 414,379 & 621,854 & 219,207 & 817,026 & 397,359 & 638,874 & $1,036,233$ & $1,912,447$ & Nineveh \\
\hline
\end{tabular}




\section{The Fourth Topic: Political Stability}

The concept of political stability in the political system is ability to employ its institutions to make the necessary changes in response to the expectations and orientations of the masses and contain conflicts that may arise and it can reach the use of political violence. While the concept of political instability refers to the inability of the political system, because of the weakness of its institutions to conduct the necessary changes in response to the demands and orientations of the masses which could lead to violence and wider conflict and undermine the legitimacy of the regime and its effectiveness (Alwan, 1990, p. 244), the political stability of any country depends primarily on the existence of strong political institutions capable of working and activity (Faeeq, 2002, p. 119). If the degree of institutional decline and the inability of these institutions to accommodate popular demands increase, it increases the vulnerability of those institutions to instability ${ }^{34}$. The presence of any political structure secures citizens' opportunities for political participation and working to expand the scope; it contributes to achieving a high level of stability and growth of the political system, and the behavior of the Iraqi voters. Some of them also confirm that it can not deal with the concept of stability purely in scientific methods, and it is imperative to note the social aspects and pattern and the prevailing value system at some point in a given period society ${ }^{35}$.

While national unity represents a fundamental basis for political stability, to resolve this problem and to promote harmony and integration is one of the elements of political stability, otherwise generates a state of political instability (Al-Khzrajy, 2004, p. 118). Interestingly, the institutional and political track is that the Iraqi elections remained within the present politics with being questioned, which is almost entrenched in a matter about the main function in a political context. The struggle within the political process remained in crisis and affected the dominance of the relations between the major political blocs and entities that claim to represent social components, controlling to a large extent in the voting trends, as well as the absence of compromise on the ground of political action.

After that, the Iraqis have exercised democracy through multiple elections since 2005. We note that the multiplicity of these elections and the consequent of the peaceful transfer of authority did not reveal the institutional stability. And it remained fragile democracy with a crisis of confidence between the political forces and social components. Democracy is more than elections. It is a realistic principled thought based on scientific rationality, building a progressive political institution, and leading social, economic, cultural and religious revolution, based on national principles and the development of active citizenship (Rasheed, 2006, pp. 26-27). Iraqi model lacked that basis, and the adoption model of political quotas on ethnic-sectarian bases. Political entities contributed significantly in the consolidation of social division through various means like mobilizing the masses through sectarian and ethnic charging, with the concentration of each party or electoral list or candidate who is defending the rights of a certain component. Each of the sect, race, religion, and tribe also became base of the party affiliation. The sectarian of political process led to transfering the political power to the competing and conflicting groups, and could not unite under a coherent political entity. This sectarianism contributed to the cut of trust and societal values, at a time, it is supposed to power political entities that work

\footnotetext{
${ }^{34}$ See: Mohammah Hardanali Alheety, Thahirat Adam Alistikraralseasy WaInikasatoha Fi Alalam Al Thalith, op. cit., p. 135, et seq.

35 See: B. C. Smith. Understanding third world politics: Theories of politics.
} 
on the promotion and development of mutual trust between the societal components it contributed to sharing ${ }^{36}$. Then the result of this sectarian of the political process led to denying the other under the logic of the loyalists. Political action in Iraq was characterized by conflicting instead of competing and interacting, disputing rather than reconciliation, and tension instead of the calm (Faiad, 2006, p. 141), which formed a barrier to the development of political consciousness and the election for the Iraqi person. And thus it remained trapped under the social component that it represents, instead of the space of national public. Sectarian and ethnic Cronyism has become a political system in which the ruling elites are working on the political exploitation of the sect and nationalism, through the slogans, rituals, and practices that are fed and supported financially and morally to win the conflict with the other, and here social division took over the movements and different entities via political form (Mahdy, 2012, p. 155). After that, those political entities managed to frame the voting behavior of voters to be a reflection of the divided social reality; those entities have contributed to establishing, and then ensured to reach its survival or head of the Iraqi political arena and this is what turned out in the results of the parliamentary elections in 2014. Because there is no reconciliation of these entities with each other, it led to a lack of respect for the election results, resulting recurrent crises in any process of forming the government, as well as delaying the work of parliament at legislative and supervisory level. Hence the inability to build political alliances is able to transport the country to the status of the desired stability.

To conclude, there is a different electoral behavior, which is a natural product of the characteristics and quality of competing political forces in these elections, as well as the nature of the ethnic structure of Iraqi society; which reflected the voting behavior of groups and individuals especially. And each component of the Iraqi people's loyalties belongs to one of the forces or political parties, which can be attributed to heavy accumulations of tyranny, exclusion, and marginalization of the political, social, and cultural past, by successive regimes which ruled Iraq, and it could be argued that voting behavior in Iraq came as representative of loyalties and ethnic, religious, national, and tribal foundation of biases.

\section{Conclusions}

Proceeding from Alkhaldoni's thought "human is a son of his environment", this man will be dependent on his environment, and without a doubt, the social environment is one of the most important of these environments; and therefore, the idea of political behavior, and the election will be determined by a social retention, framed by the values and convictions, and ideas of society are common among its members who have the social consciousness of the individual. The individual derives its strength from the strength of the existing attractions at the heart of ethnic, tribal, and sectarian regime in control of the social relations, and the employment of partisan and political forces that would prevent an individual from this system exceeds keeping it in his feelings and behavior of prisoners of sectarian, ethnic, and tribal individual. As one of the results of the historical heritage, based on coercion and persecution and sectarian national practiced by successive governments over nearly one century, a number of political entities have contributed factional mobilization means to establish psychological fissures and social division, and distribute the loyalties according to ethnic, religious, sectarian, and tribal formations, which are reflected negatively on the voting behavior of the electorate who are warm-hearted behind the symbols of sectarianism. It has contributed to the weakness of the national reformist orientation of many of the forces and political parties and blocs, which continued a narrow

${ }^{36}$ See: Waleed Salim Mohammad, op. cit., pp. 345-346. 
factional interest in its orientations and interests without going out of the national space. The election results revealed that the voting behavior of a large segment, perhaps the largest in the Iraqi society did not depart from the influence of political factionalism at sectarian and ethnic level, as well as the impact of individualism, without much attention to the programs of the electoral lists competing, leading to reproducing the same ruling political blocs production, with some changes in the electoral weights. The electoral system also appeared as an important delimiter and was influential on Iraqi voters' voting direction, and motivated them to vote on the basis of narrow factional affiliation for the most part, not on the basis of national political programs of the competing electoral lists. The electoral system became the band factor rather than a unit factor.

The electoral rolls for a number of patterns of voting behavior in Iraq, including:

(1) The first pattern of behavior: loyal ideological leaders of a religious nature of sectarian or national in order to restrengthen the principles and elements of religion and caste;

(2) The second behavior pattern is a supporter of traditional nationalist party and clan leaders, in order to maintain the existing trends affiliations and interests associated with them;

(3) The third pattern is a style supporter of the current and civilian forces (liberal and secular), a relatively limited pattern in terms of the impact on voting behavior;

(4) The adoption of the principle of consensual democracy, renamed in Iraq, sectarian or ethnic quota system, to negative results, includes the absence of strategic voter and the emergence of ideology voter, loaded with hatred, ethnic, and sectarian contract. Through evoking the history of the marginalization of the component or segment or a particular social group, it is indifferent to what is produced by the election results on the basis of the National Democratic Electoral Act. Despite the continued presence of virtual social component and the manifestation of the community-nationalist-tribe and other forms of traditional loyalties, some functions on the relative development indicators have emerged in the degree of electoral awareness among Iraqi citizens which is represented in:

(a) Relative increase in the number of candidates, and the candidates competing for the seat in all electoral constituencies;

(b) Increasing proportions of the vote for women, participation rates, and vote rated, particularly among young people with the high proportion of the number of candidates who took graduate certificates.

It is one of the signs of indicators constituting a rational voting behavior that is completed, which can develop with the repetition of electoral processes.

Based on research data which clearly showed the impact of the traditional factors of sectarian, ethnic, tribal, and retreated to some extent of democracy and individual factors such as political programs and individual characteristics of the candidates, we propose a set of recommendations associated with multi-party development of the electoral awareness of the Iraqi people; and then the evolution of electoral behavior must be within the framework of community context, broadly; we need an integrated combination which includes a number of political institutions and educational share, and civil society organizations; and among the most important of those coming recommendations:

(1) Work on the development of the Iraqi people's voting behavior, through the establishment of political development projects, which could contribute to the development of the political and electoral awareness for individuals;

(2) Attention to educational institutions, through the development of curricula and programs that focus on the importance of citizenship and the promotion of tolerance and peaceful coexistence, and renunciation of 
repulsive values such as sectarian, ethnic, and the adoption of the university national identity;

(3) To deepen culture of citizenship, through educational and media and political programs, with the institutions of civil society development;

(4) Working on the rationalization of voting behavior, through the adoption of a new electoral system, to give the voter more than one vote, or be allowed to arrange candidates in preferential order to enable voters to bypass the traditional social boundaries is also the case in many of the same multi-ethnic states.

\section{References}

Alduekat, K. (2002). Geopolitics. Oman: Mutah University.

Alhaso, N. T. S. (1984). The conflict on power in the royal Iraq. Analytical study in administration and politics. The Canadian Library, Baghdad.

Al-Khzrajy, T. K. (2004). Modern political systems and public policies. Amman: Dar Al-Majdalawi.

Allekani, A. H. (1999). Glossary of educational terms: Knowledge in curriculum and teaching methods. World of books, Cairo.

Alwaelly, W. M. A. (2012). The political participation of the Iraqi woman: A comparative study in women's Kota. Beirut: Al-Rafidain for Printing, Publishing and Distributing.

Alwan, H. (1990). The problem of the political participation in the developing countries (the African pattern). Doctoral thesis, Faculty of Political Science, University of Baghdad.

Assadwatfa, A. (2003). Political and social challenges in Kuwait and the Arab world. Discuss the implications of political awareness at Kuwait University students. Alam Alfikir Magazine, January-March 2003, Kuwait.

Awad, A. H. (2010). Political sociology. Alexandria: Modern University Office.

Dovreign, M. (2011). Political parties. (A. Imitator \& S. Abdul-Muhsin, Trans.). Cairo: The General Authority for Failure Althagaqh.

Faeeq, M. (2002). Human rights and development. Almustaqbal Alarabi Journal, no. 276. The Center for Arab Unity Studies, Beirut.

Faiad, A. H. (2006). Iraq and the misery of democracy. Oman: Dar Osama Lel Nashir Wa Altawzee.

Huntington, S. (1993). The political system of the changing societies. (F. I. Abboud, Trans.). Beirut: Saqi Books.

Independent Electoral Commission. (2006). A historic three elections in one year.

Independent Electoral Commission. (2014). The comprehensive report of the department of operations, to the House of Representatives election and provincial councils. Kurdistan.

Jawad, B. M. (2013). The role of the Iraqi woman in the democratic system. Damascus: Dar Alhasad.

Kayali, A. W. (1994). Encyclopedia of politics (Part 7). Beirut: The Arab Association for Studies and Publishing.

Lawyers and the American Association of Magistrates. (2006). The development of law in Iraq project (ABA-ILDP), the status of women in Iraq.

Mahdy, M. J. (2012). The problem of democracy in Iraq after 2003. Al-Mustaqbal Alarabi Magazine, number 405, the Center for Arab Unity Studies, Beirut.

Mousaad, N. (2008). Integrity in the parliamentary elections. Beirut: The Center for Arab Unity Studies.

Nadhmi, W. J. O. (1985). The political, intellectual and social roots of the Arab national movement. Independence in Iraq (2nd ed.). Beirut: The Center for Arab Unity Studies.

Rasheed, A. W. H. (2006). The democratic transition in Iraq. Beirut: Al-Wahda Al-Arabia Studies Center.

Salem, M. S. (2011). The locative variation in the participation average of the voters. In Proceedings of the First Conference of the Independent High Electoral Commission, Baghdad.

Shatawe, M. (1997). Jordanian political elections in 1997: A sociological analysis. In the group of researchers, studies in Jordan's parliamentary elections in 1997.

Yosef, I. A. (2001). Political and electoral awareness for university students. Egyptian Journal of Research of Public Opinion, 2(1), 72. Faculty of Information, Cairo University. 